\title{
Influence of Potash Fertilizers on Tobacco Yields and Quality on a Mabí Clay
}

\author{
G. Samuets, F. González-Vélez, E. G. Boneta-García, and A. Sierra-Bracero'
}

\section{INTRODUCTION}

About 20 percent of the cost of growing tobacco is attributable to fertilizers. At present the farmer has two fertilizer analyses to choose from, a 6-8-10 or a 8-6-10. Either grade offers 10 units of potash, or 100 pounds of $\mathrm{K}_{2} \mathrm{O}$ per 1,000 pounds of mixed fertilizer. The use of more potash than of either nitrogen or phosphates in local tobacco fertilizer analyses is normally justified by the statement that large quantities of potash are needed to produce a good-quality cigar tobacco. However, no research has been done in Puerto Rico to ascertain the potash actually needed for optimum yields and high quality in cigar-filler tobacco.

This paper deals with the response of tobacco to various potash applications on a Mabi clay, and the quality of cigars produced from the various potash treatments.

\section{PROCEDURE}

The experiment involved four levels of potash $\left(\mathrm{K}_{2} \mathrm{O}\right): 0,100,200$, and 300 pounds per acre. An additional treatment consisted of the 200 pounds of $\mathrm{K}_{2} \mathrm{O}$ plus 2 tons of lime per acre. All treatments received nitrogen and phosphate at the rate of 100 pounds $\mathrm{N}$ and 200 pounds $\mathrm{P}_{2} \mathrm{O}_{5}$ per acre, respectively. The fertilizer was applied to the soil 10 days after planting the tobacco seedlings; it was placed in small semicircular bands at opposite sides of the plant and then covered with soil. The fertilizer sources were ammonium sulfate (20-percent $\mathrm{N}$ ), superphosphate (20-percent $\mathrm{P}_{2} \mathrm{O}_{5}$ ), and potassium sulfate $\left(50\right.$-percent $\left.\mathrm{K}_{2} \mathrm{O}\right)$. The ground limestone used contained 93 percent of $\mathrm{CaCO}_{3}$, and was applied 3 weeks before planting and thoroughly incorporated with a hoe into the upper 3 inches of soil.

The soil used was classified as a Mabí clay with a $\mathrm{pH} 5.6$ for the 0-8 inches plowed layer. This soil is a grayish-brown plastic heavy clay which has a good tilth when properly cultivated.

The experiment was laid out in a paired-plot design having five treatments and four replications. The plot size was 21 feet wide and $22 \frac{1}{2}$ feet long, or approximately 1/92 acre in area. Each plot had 6 rows, 42 inches apart, with 15 tobacco plants 18 inches apart in the row, making a total of

${ }^{1}$ Agronomist, and Research Assistants in Agronomy, respectively, Agricultural Experiment Station, and Gurabo Substation, University of Puerto Rico, Río Piedras, P.R. 
90 plants per plot. Seedlings were selected for uniformity in size and development and carefully transplanted to the experimental plots. All mosaic-infected plants were discarded. Seedlings were replanted, if needed, 10 days after the first planting.

The tobacco leaves were picked every 8 to 10 days after the first picking was made. All plants were pinched back (topped) after they were fully grown, to prevent flowering and induce enlargement of the leaves. The tobacco leaves collected from each plot at each picking were promptly identified and hung in racks in the tobacco barn for drying. After the leaves were dried they were classified, using the standard grades for Puerto Rican cigar-leaf tobacco (U.S. Type 46), as designated by the Tobacco Division, Agricultural Marketing Service, U.S. Department of Agriculture. The classified air-cured tobacco was then weighed. The cash value of each treatment was calculated from the sum of the products of the yield of each standard grade and the price per pound of each grade. The average price received per pound of tobacco for the various treatments was calculated by dividing the cash value per acre of the cured tobacco by the total poundyield per acre of tobacco produced.

The weighed and cured tobacco were fermented and cigars were made from that grown under the various potash levels. The cigars were smoked by a panel of cigar smokers. A questionnaire was given to each cigar smoker for evaluating the cigars. Each smoker received five cigars, one from each treatment, and a total of 48 smokers participated in the test.

\section{RESULTS}

\section{YIELDS}

There were increased yields of tobacco as the rate of potash fertilizer application increased. The usc of 300 pounds per acre of $\mathrm{K}_{2} \mathrm{O}$ gave 3.34 hundredweights more cured tobacco per acre than the no-potash treatment (table 1.) However, the use of 100 and 200 pounds of $\mathrm{KO}_{2}$ per acre failed to give significant yield increases over the no-potash treatment.

The addition of each 100-pound increment of $\mathrm{K}_{2} \mathrm{O}$ per acre did not give rise to the normal yield increases expected under the law of diminishing increments of yields. Usually, as we increase a fertilizer application by equal increments, the yields of crops are also increased, but at a diminishing rate.

However, in this experiment the application of 100-pound increments of $\mathrm{K}_{2} \mathrm{O}$ per acre from 0 to 300 pounds brought about increasing tobacco yields of $0.98,1.02$, and 1.34 hundredweight. The tendency of tobacco yields to increase with increasing potash applications might be attributed to the fact that the initial applications of potash were used to satisfy a "potassium- 
fixation" in the soil. Therefore, increasing amounts of potash were needed to overcome this inertia caused by the potassium being made relatively unavailable to the plant. After the potassium requirement of the soil had been satisfied, the additional potassium was available to the plant roots. If more increments had been used, the addition of further amounts of $\mathrm{K}_{2} \mathrm{O}$ would have probably given rise to a diminishing rate of yield increase.

The use of lime with the potash application gave a significant increase of 4.48 hundredweights of cured tobacco over the no-potash treatment (table 1). The yield increase was not significant when compared with that produced by only 200 pounds of $\mathrm{K}_{2} \mathrm{O}$ per acre.

TABLE 1.-Yields and prices of cigar-filler tobacco grown at various potash levels on a Mabi clay at Gurabo

\begin{tabular}{|c|c|c|c|c|}
\hline $\begin{array}{l}\text { Treatment' in pounds of potash }\left(\mathrm{K}_{2} \mathrm{O}\right) \\
\text { and tons of lime per acre }\end{array}$ & $\begin{array}{c}\begin{array}{c}\text { Yield of } \\
\text { cured tobacco } \\
\text { per acre }\end{array} \\
\text {. }\end{array}$ & $\begin{array}{l}\text { Price of } \\
\text { cured tobacco } \\
\text { per acre }\end{array}$ & $\begin{array}{c}\text { Price of } \\
\text { cured tobacco } \\
\text { per pound }\end{array}$ & $\begin{array}{l}\text { Price of cured } \\
\text { tobacco per acre } \\
\text { after deducting } \\
\text { fertilizer costs }\end{array}$ \\
\hline $\begin{array}{l}0 \\
100 \\
200 \\
300 \\
200+2 \text { of lime }\end{array}$ & $\begin{array}{c}C w t . \\
10.96 \\
11.94 \\
12.96 \\
14.30 \\
15.44\end{array}$ & $\begin{array}{c}\text { Dollars } \\
324 \\
405 \\
421 \\
480 \\
526\end{array}$ & $\begin{array}{l}\text { Cents } \\
30 \\
34 \\
37 \\
34 \\
34\end{array}$ & $\begin{array}{c}\text { Dollars } \\
324 \\
398 \\
409 \\
461 \\
493\end{array}$ \\
\hline $\begin{array}{l}\text { Least significant difference be- } \\
\text { tween treatments at: } \\
\text { 5-percent level } \\
\text { 1-percent level }\end{array}$ & $\begin{array}{l}3.33 \\
4.99\end{array}$ & 123 & 3.7 & \\
\hline
\end{tabular}

1 All treatments received $100 \mathrm{lb}$. of nitrogen and $200 \mathrm{lb}$. of $\mathrm{P}_{2} \mathrm{O}_{6}$ per acre, respectively.

\section{QUALITY}

Consideration of the quality of the tobacco produced with potash fertilization revealed that the quality increased with increased potash fertilizer application. As measured by dollar returns per acre, the use of 300 pounds of $\mathrm{K}_{2} \mathrm{O}$ per acre gave a significant increase of $\$ 156$ per acre over the no-potash treatment (table 1 ).

On a basis of cured tobacco, the use of 100 pounds per acre of $K_{2} \mathrm{O}$ gave tobacco at 35 cents per pound as compared to 33 cents for the no-potash treatment. The use of 200 pounds of $\mathrm{K}_{2} \mathrm{O}$ per acre raised the per pound price to 37 cents, but 300 pounds of $\mathrm{K}_{2} \mathrm{O}$ per acre failed to give any worth-while higher price. Thus, from the point of best quality, the use of 200 pounds of $\mathrm{K}_{2} \mathrm{O}$ per acre was sufficient, whereas, the extra gain in yield of tobacco 
made the 300 pounds of $\mathrm{K}_{2} \mathrm{O}$ per acre the highest cash yielder per acre of tobacco sold.

Lime in combination with potash failed to increase the tobacco quality as compared with potash only, at least as measured by the price received per pound of tobacco. The increase was only 1 cent from 33 to 34 cents when comparing lime-potash with potash treatments.

A consideration of cost of the potash fertilizer used was given in reevaluating the price received for the tobacco from each treatment. The prices obtained from sale of the cured tobacco after the cost of the potash fertilizer and lime had been subtracted are given in the last column of table 1. The use of 300 pounds of $\mathrm{K}_{2} \mathrm{O}$ plus 2 tons of lime per acre still gave considerable returns for their use in fertilizing tobacco.

It appears from the results of this experiment that, for the Mabi clay soils of Gurabo, fertilizer grades high in potash are of value for producing tobacco yields and quality, as to price received for the classified cured tobacco.

The cigars made from tobaccos grown under the various potash treatments did not reveal any significant difference in qualitative factors relating to smoker acceptability (table 2). In general, the cigar produced was mild, moderately agreeable in taste, with a plain aroma of the smoke, hardly any irritation, a below-average combustibility or burning quality, and greyish-black ash color. Hardly any differences or consistent trends were noted with the potash treatments for any of the quality factors tested.

\section{SUMMARY}

An experiment with increasing applications of potash, with, and without lime in one instance, on cigar-filler tobacco on a Mabi clay at the Gurabo Substation gave results as follows:

1. There were increased yields of tobacco as the rate of potash fertilizer application increased. The use of 300 pounds per acre of $\mathrm{K}_{2} \mathrm{O}$ gave a significant increase over the no-potash treatment, but 100 and 200 pounds of $\mathrm{K}_{2} \mathrm{O}$ per acre failed to do so.

2. The use of 2 tons of lime plus 200 pounds of $\mathrm{K}_{2} \mathrm{O}$ per acre produced significant increases in yields of cured tobacco over the no-potash treatment, but did not when compared to the 200 pounds of $\mathrm{K}_{2} \mathrm{O}$ per treatment.

3. The quality of the tobacco, as measured by price received per pound of cured tobacco, was highest for the treatment with 200 pounds of $\mathrm{K}_{2} \mathrm{O}$ per acre.

4. Considering the cash return received by the farmer for his cured tobacco, after deduction of fertilizer costs, the use of 2 tons of lime and 200 pounds of $\mathrm{K}_{2} \mathrm{O}$ per acre appeared to be the most profitable treatment. 


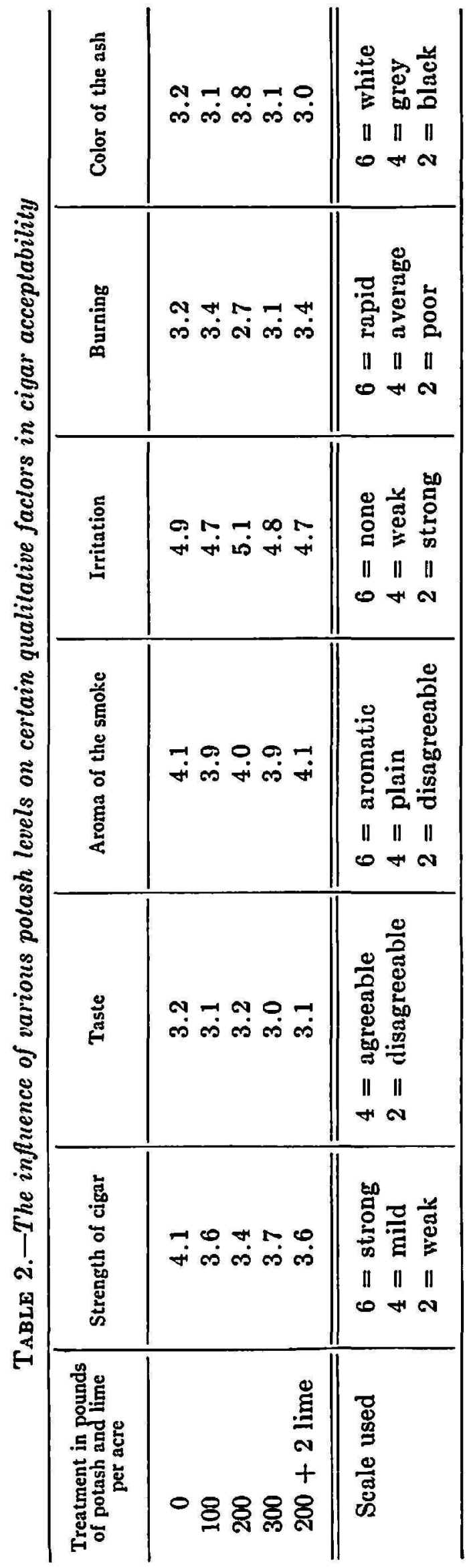


5. Cigars made with tobacco from the various potash treatments displayed no significant differences in quality factors affecting smoker acceptability.

\section{RESUMEN}

Un experimento con abonos para tabaco de tripa, en arcilla Mabí en la Subestación de Gurabo, y en el cual se aumentaron los niveles de potasa desde 0 hasta 300 libras por cuerda $(0,100,200,300)$, reveló lo siguiente:

1. Hubo aumento de los rendimientos de tabaco, según aumentaron las proporciones de potasa. El uso de 300 libras de $\mathrm{K}_{2} \mathrm{O}$ por cuerda produjo un aumento significativo sobre el tratamiento sin potasa, pero éste no fue significativo cuando se comparó con el tratamiento de 200 libras de $\mathrm{K}_{2} \mathrm{O}$ por cuerda.

2. El uso de 2 toneladas de cal, más 200 libras de $\mathrm{K}_{2} \mathrm{O}$ por cuerda, produjo aumentos significativos en cuanto al tabaco curado sobre el tratamiento sin potasa, pero esto no resultó así cuando se compararon con los resultados del tratamiento de 200 libras de $\mathrm{K}_{2} \mathrm{O}$ por cuerda.

3. El tratamiento de 200 libras de $\mathrm{K}_{2} \mathrm{O}$ por cuerda produjo el tabaco curado de mejor calidad, según se determinó al computar el precio pagado por el producto.

4. Si se considera el ingreso del agricultor por el tabaco curado después de restur el costo del abono, puede afirmarse que el tratamiento más remunerativo fue el que consistió de la aplicación de 2 toneladas de cal y 200 libras de $\mathrm{K}_{2} \mathrm{O}$ por cuerda.

5. En cuanto a la aceptación de los fumadores, no hubo diferencias significativas entre los distintos tratamientos con potasa, en lo concerniente a los factores de calidad. 